http://dx.doi.org/10.12775/szhf.2013.036

Krzysztof Wawrzonkowski

\title{
Ostatni człowiek a idea pokolenia, czyli jak Fukuyama odkrywał naturę ludzką
}

Ostatni człowiek ${ }^{1}$ Francisa Fukuyamy, praca wydana w Polsce jako osobne dzieło, jest drugą częścią rozważań zawartych w Końcu historii ${ }^{2}$. W tej części autor nie koncentruje się jednak na analizie rozwoju nauk przyrodniczych jako podstawie dla rozwoju gospodarczego oraz zagadnieniu sensu samego procesu postępu i możliwości jego odwrócenia, lecz zwraca się w stronę rozważań zapowiedzianych już wcześniej, poświęconych napędzającej bieg historii ludzkiej potrzebie uznania. Teza, jaką Fukuyama postawił - nadchodzący koniec historii powiązany jest $\mathrm{z}$ zastąpieniem potrzeby uznania poprzez osiągniecie przez ostatnich ludzi równości i wzajemnego uznania w demokracjach liberalnych państw homogenicznych - wymaga jednakże, aby gruntownie przeanalizować zawarte w niej przesłanki. Przede wszystkim należy sprawdzić, czy natura ludzka, której istnienie Fukuyama przyjmuje bez zastrzeżeń, pozwala na określenie istoty ostatniego człowieka, a także, czy napędzający zdaniem Fukuyamy bieg historii platoński thymos, leżący również u podstawy heglowskiej koncepcji potrzeby uznania, pozwala na wyciągnięcie tak daleko idących wniosków, jak te zaprezentowane w Ostatnim człowieku, a dotyczące funkcjonowania człowieka w świecie. Ostatni człowiek żyjący w dobie końca historii miałby bowiem niejako sublimować thymos w innych działaniach niż tylko odwieczne walki, lecz nadal potwierdzających

\footnotetext{
${ }^{1}$ F. Fukuyama, Ostatni człowiek, tłum. T. Bieroń, Poznań 1997.

${ }^{2}$ F. Fukuyama, Koniec historii, tłum. T. Bieroń, M. Wichrowski, Poznań 1996.
} 
jego wyższość nad innymi ludźmi. Walka o uznanie miałaby przybrać inną formę i realizować się na płaszczyźnie chociażby sportowej lub ekonomicznej. Jednak, jak skądinąd słusznie zauważa Fukuyama, coraz częściej staje się problematyczny brak stałego horyzontu wartości wypływających z demokratycznej tolerancji dla innych jednostek i ich hierarchii wartości. Skoro każdy ma prawo do uznania swego świata aksjologicznego za równie wartościowy, to na jakiej podstawie toczyć potyczki i oceniać jednych lepiej od drugich? Jak wówczas może zostać zrealizowana potrzeba uznania i jak ma zaspokoić potrzeby obywatela? Tolerancja i należące do jego światopoglądu powstałe w nowożytności poszanowanie godności innych odbierają mu kryterium oceny samego siebie. Fakt, że nadal potrafimy być dumni, czegoś się wstydzić lub czuć się upokorzeni świadczy o tym, że megalothymia - potrzeba uznania za lepszego od innych, wciąż jest silniejsza i bardziej zagraża demokracji niż izothymia, czyli potrzeba wzajemnego uznania za równych. Oznacza to więc, że znalezienie dla thymos ujścia w konsumpcyjnym wyścigu, etosie pracy, wolnej przedsiębiorczości lub innych formach działalności gospodarczej wcale nie jest takie oczywiste. Tym samym Fukuyama może mieć problem $\mathrm{z}$ udowodnieniem swych tez, a z pewnością $\mathrm{z}$ właściwym pojmowaniem natury ludzkiej - bo czyż thymos można opanować na dobre? Czy w platońskim rydwanie woźnica zdoła całkowicie poskromić białego konia?

By rozjaśnić nieco rolę thymos w ludzkim życiu, przyjrzymy się jak funkcjonuje on w przywoływanej przez Fukuyamę platońskiej koncepcji duszy, by następnie prześledzić jego losy w filozofii Hobbesa i Rousseau. To właśnie ich poglądy filozof przywołuje na kartach swych prac, kreśląc przy tym, jak się wydaje, wykoślawiony obraz ludzkiej potrzeby uznania.

Punktem wyjścia dla prowadzonych tu rozważań jest próba określenia sposobu zakorzenienia człowieka w świecie i napędzania przez niego biegu wydarzeń, oparta na przedstawionej przez Josè Ortegę y Gasseta idei pokolenia. Hiszpański filozof nie pozostawiał żadnych złudzeń co do możliwości osiągnięcia kresu historii i wskazywał na stałe tworzenie przez człowieka nowej rzeczywistości. Daleki był również od optymizmu Fukuyamy dotyczącego demokracji jako najdoskonalszej formy ustroju, życie człowieka ukazywał zaś z perspektywy wiecznego dramatu zderzającej się ze światem jednostki. Koncepcja Ortegi y Gasseta zawiera ważne uzupełnienie tez stawianych przez amerykańskiego politologa i futurologa, który nie poświęca $\mathrm{w}$ ogóle uwagi pojedynczym ludziom i ich prywatnej perspektywie oglądu świata, w którym żyją. Nie znajdziemy w nich analiz poświęconych przeżywaniu przez człowieka jego życia i świata, który przyszło mu współtworzyć. Takie podejście 
dominuje natomiast w myśli autora Dehumanizacji sztuki. Człowiek jest tutaj w centrum uwagi i jego oczami oglądany jest ludzki świat. Jak bez takich analiz rozważać ludzką naturę?

Już na początku swego dzieła Wokół Galileusza Gasset słusznie zauważa, że:

Człowiek nie może uczynić ani jednego kroku, nie antycypując z mniejszą lub większą dozą jasności swojej przyszłości, tego, czym ma być; innymi słowy tego, czym zdecydował się być w czasie całego życia. Oznacza to jednak, że jeżeli człowiek, zawsze zmuszony do robienia czegoś w danej okoliczności, ma zadecydować, co ma robić, musi stanąć wobec problemu własnego indywidualnego bytu [...] Każdy bowiem, kto stawia sobie pytanie, czym ma być, a zatem, czym ma być jego życie, musi stanąć wobec problemu, jaki jest byt człowieka, czym jest to, czym człowiek na ogół może być, i czym jest to, czym musi być. To zaś z kolei zmusza do wypracowania sobie idei, do przebadania w jakiś sposób, czym jest okoliczność, otoczenie lub świat, w jakim człowiek żyje. Rzeczy, które nas otaczają, same z siebie nie mówią nam, czym są. Sami musimy to odkryć. Takie odkrywanie bytu rzeczy i własnego bytu, bytu wszystkiego, jest intelektualnym trudem człowieka, który nie jest przeto jakimś zbytecznym i zewnętrznym dodatkiem do jego życia, lecz jego elementem konstytutywnym, czy człowiek sobie tego życzy, czy nie. A zatem sprawa nie przedstawia się tak, że człowiek żyje i następnie - o ile poczuje jakąśs szczególną ciekawość - zajmuje się wypracowaniem pewnych idei o rzeczach. Nie: sam bowiem fakt życia zmusza nas już do jego interpretowania. Zawsze, w każdej chwili, nieodwołalnie, stajemy wobec naszych zakorzenionych przekonań, czym są rzeczy i my pośród nich; otóż na mocy powiązania tych ostatecznych przekonań nasza chaotyczna sytuacja przeradza się w jedność pewnego świata, czyli universum ${ }^{3}$.

Zderzając się ze światem, już od pierwszych chwil socjalizacji tworzymy sobie indywidualne wyobrażenia świata, a tym samym tworzymy własną rzeczywistość. Te same wydarzenia w życiu różnych osób odgrywają inną rolę i mają odmienne znaczenie. Posłużmy się w tym miejscu pewnym przykładem: sukces pływaka zwieńczony złotym medalem jest dla niego powodem do dumy, dla rywalizujących z nim przeciwników oznacza zaś porażkę. Trener zwycięzcy zyskuje potwierdzenie właściwego doboru ćwiczeń, harmonogramu zadań i sposobu prowadzenia zawodnika. Dla trenerów jego oponentów jest to sygnał do zmiany określonego modelu treningów. Jednak na tym nie koniec. Pojedyncze wydarzenie odgrywa bowiem rolę w życiu wielu

${ }^{3}$ J. Ortega y Gasset, Wokół Galileusza, tłum. E. Burska, Warszawa 1993, s. 17. 
innych osób. Gdzieś w tym wszystkim są przecież sędziowie z ich dążeniem do rzetelności w pomiarach, burmistrz miasta podpisujący zgodę na budowę obiektu sportowego, który wpisując się w budżet miasta zwraca poniesione nań wydatki, kibice $\mathrm{z}$ ich radością lub zawiedzionymi nadziejami, a nawet miejski zakład wodno-kanalizacyjny dostarczający za opłatą wodę. Każdy uczestnik tego wydarzenia - wydawałoby się zwykłego wyścigu pływaków uczestnicząc w nim, ustanawia je jednocześnie częścią własnej rzeczywistości, ta zaś niczym ? aktualizuje się, każdorazowo rozbijając przy tym swą poprzednią „treść. W tym zderzaniu się ze światem nikt nie jest osamotniony. $\mathrm{Z}$ jednej bowiem strony ten rozbijany lub aktualizowany świat sami wnosimy w kolejne okoliczności, z drugiej jednak jest on wynikiem pracy poprzednich pokoleń, która kumuluje się w sposób stały w historii. Wrastając w kulturę, przejmujemy panujące $w$ niej wzorce zachowań, hierarchie wartości, mniej lub bardziej rzetelne oceny, dogmaty i pokutujące błędne przeświadczenia i stereotypy. Chcąc nie chcąc, powielamy je, stanowią one bowiem integralną część nas samych, wychowaliśmy się na nich i z nich czerpiemy nasze "pierwotne" wyobrażenie świata.

Idea świata czy universum jest planem - jak zauważa Gasset - który człowiek, chcąc, nie chcąc, wypracowuje, aby poruszać się wśród rzeczy i realizować swoje życie, aby orientować się w chaosie okoliczności. Zarazem jednak okazuje się, że idea ta została mu dana przez jego otoczenie, że jest to idea w jego czasie panująca. Musi zatem z nią żyć, bądź ją akceptując, bądź niektóre z jej aspektów podważając. Wszelako człowiek nie zajmuje się tylko myśleniem o rzeczach czy zdobywaniem wiedzy, wytwarza on narzędzia, rozmaite sprzęty, współżyje z techniką; okoliczności zmieniają się w zależności od stopnia rozwoju techniki, jaki istnieje w momencie jego narodzin. Dzisiaj problemy materialne nie są już tak nękające jak w paleolicie. Co innego zajmuje teraz uwagę. Życie człowieka jest przeto identyczne w swej podstawowej strukturze, lecz różni się perspektywą problemów. Zawsze czymś się w życiu zajmujemy, lecz w każdej epoce jest coś, co najbardziej zaprząta uwagę .

Stale zderzamy się ze światem; stworzony produkt naszych przekonań jest więc stałym elementem ludzkiej egzystencji. A żyjąc w społeczeństwie jesteśmy narażeni na konfrontowanie tego produktu z wyobrażeniami sąsiada, kolegi, maszynisty i innych. Wzajemnie wzbogacamy swe światy traktując jednak innych jako część naszego universum. Ta indywidualna perspektywa

${ }^{4}$ Tamże, s. 19. 
dotyczy każdego, każdy bowiem tworzy tego typu narzędzie - wyobrażony świat - by czuć się bezpiecznie. W ten sposób stwarzamy własny horyzont wartości, w świetle którego następnie ujmujemy panującego w danym okresie ducha czasu lub epoki, który jest niczym innym, jak światem zbiorowych przeświadczeń wyznawanych przez anonimowy podmiot. One zaś funkcjonują, obowiązując niezależnie od tego, czy je uznajemy, czy też nie. A mimo tego zderzamy się z nimi, a więc i musimy na nie reagować.

Ludzkie życie z perspektywy filozofii Gasseta to żądza bycia, tę zaś może

odczuwać tylko ktoś, kto nie ma pewności bycia, kto stale odczuwa jako problematyczne to, czy będzie lub nie w danym momencie i czy będzie taki lub inny w ten lub inny sposób. Nasze życie jest żądzą bycia, ponieważ zarazem u swych korzeni jest zasadniczą niepewnością. Dlatego zawsze staramy się zabezpieczyć sobie życie i zanim cokolwiek postanowimy, interpretujemy okoliczności, w których przyszło nam być i interpretujemy siebie samych, usiłując w nich być, zakreślając tym jedyny horyzont naszego życia. Interpretacja owa dokonuje się w ramach tego, co nazywamy »naszymi przekonaniami« $[\ldots]$ A całokształt pewności, jakie rozważając naszą okoliczność zdołamy w sobie ukształtować, stworzyć, jest światem, życiowym horyzontem. Płynie stąd wniosek, że człowiek aby żyć, musi myśleć, wyrabiać w sobie przekonania; innymi słowy, żyć to reagować na podstawową niepewność przez przebudowanie jakiegoś rodzaju pewności lub wiary, że świat jest w ten lub inny sposób, aby w tej perspektywie kierować swoim życiem, żyćs.

Reakcja na zastany świat, tak jak ją przedstawia Gasset, okazuje się narzędziem zaspokajającym nasze poczucie bezpieczeństwa. Tworząc rzeczywistość, tworzymy universum, zapewniamy sobie schronienie i spokój, wzorce zachowań i kryteria ocen, wyjaśnienie praw rządzących przyrodą i relacjami międzyludzkimi. Co jednak napędza bieg dziejów? Co powoduje, że wszystko, co znamy zmienia się i rozwija w jakimś kierunku? I wreszcie, co sprawia, że tego procesu nic już nie zatrzyma?

Odpowiedź leży w idei pokolenia. Zdaniem Gasseta możemy sformułować dwie zasady konstruowania historii. Po pierwsze, człowiek stale wytwarza świat, kształtując tym samym swój horyzont. Po drugie, każda zachodząca w nim zmiana przekształca strukturę dramatu życia. Gasset podkreśla, że „żyjący podmiot psychofizjologiczny, dusza i ciało człowieka może się nie zmienić, zmienia się jednak jego życie, ponieważ zmienił się świat. Otóż

${ }^{5}$ Tamże, s. 25. 
człowiek nie jest swoją duszą i swoim ciałem, lecz swoim życiem, bohaterem swego witalnego problemu. Przedmiot historii daje się zatem w sposób formalny określić jako studium form czy struktur życia ludzkiego od czasu istnienia świadectw" ". Struktury życia ludzkiego nie zmieniają się jednak ot tak po prostu. Zmiany tej nie odczuwamy na każdym kroku, choć stale budujemy nowe światy. Trzyletnie dziecko posługujące się już dość sprawnie mową jak na wymogi porozumienia z innymi i nazywania części własnych stanów emocjonalnych i otaczających go rzeczy w świecie, również stale buduje swoje universum. Gromadząc wiedzę przekazywaną przez rodziców, wychowawców w przedszkolu, opiekunki czy wreszcie bohaterów bajek, tworzy własny horyzont, w ramach którego interpretuje dramat własnego życia. Potrzeba bezpieczeństwa u tak małego dziecka rzecz jasna uwydatnia się dużo bardziej niż w przypadku osób dorosłych. A już z pewnością jest ona innego rodzaju. Nazywanie jednak rzeczy po imieniu pozwala orientować się w świecie. Dowiadując się, że to, co czuje do niewidzianej od dawna cioci nazywa się tęsknotą, zyskuje nowy oręż w walce ze światem. Bez większego problemu będzie wiedziała kiedy go użyć, by zyskać od przyjeżdżającej cioci upragniony prezent: „Tęskniłam za tobą ciociu”. Reakcji tej ostatniej nie muszę chyba opisywać.

Przedstawiony mechanizm odnajdywania się w świecie należy rozciągnąć na wszystkich ludzi. Każdy z nas uczy się orientować w świecie. Każdy z nas tworzy jego wyobrażenie i traktuje jak narzędzie w walce trwającej przecież każdego dnia. Zdobywana wiedza jest, jak to często podkreśla Gasset, własnością wszystkich i w zasadzie niczyją. Wyznaje ją podmiot anonimowy, społeczeństwo i zawiera się ona w duchu epoki. Analizując to zagadnienie, Gasset zauważa, że:

Historia nie zajmuje się wyłącznie konkretnym życiem indywidualnym; nawet wtedy, kiedy historyk zamierza stworzyć biografię jakiejś postaci, odkrywa, iż jej życie wplątane jest $\mathrm{w}$ życie innych ludzi, a tych z kolei - w życie jeszcze innych - czyli, że każde życie jest zanurzone w jakichś określonych okolicznościach życia zbiorowego. I to życie zbiorowe, anonimowe, z którym każdy z nas się styka, ma także swój świat, swój repertuar przekonań, z jakimi jednostka, chcąc nie chcąc, musi się liczyć. Co więcej, ten świat zbiorowych przeświadczeń, które zwykło się nazywać »ideami epoki«, »duchem czasu«, ma szczególny charakter, jakiego nie posiada świat przeświadczeń jednostkowych; otóż jest on sam z siebie obowiązujący niezależnie od tego, czy go akceptujemy, czy nie.

${ }^{6}$ Tamże, s. 28. 
Moje nawet najbardziej stałe przekonanie zachowuje ważność tylko dla mnie. Zaś idee czasu, środowiskowe przekonania wyznaje podmiot anonimowy; nie jest nim jednostka, lecz społeczeństwo. Idee te zachowują ważność, nawet gdybym ich nie akceptował [...] Jest jednak jasne, że duch czasu wywiera na każde życie przeważający wpływ bynajmniej nie dlatego, że po prostu jest czy - na jedno wychodzi - że ja jestem w nim i w nim muszę się poruszać, i być, lecz dlatego że znaczna część mego świata, moich przeświadczeń pochodzi w istocie z owego kolektywnego repertuaru, że jest z nim zbieżna. Duch czasu, idee epoki w swojej olbrzymiej i przeważającej części tkwią we mnie, są moje. Od momentu narodzin człowiek stale przyswaja sobie przekonania swego czasu, czyli że stale odkrywa siebie w obowiązującym świecie ${ }^{7}$.

Ten obowiązujący świat to świat zastany, skąd jednak on sam wziął swój początek? Ktoś musiał przecież go wytworzyć. Proces ten zachodzi w czasie i wymaga współpracy ludzi w różnym wieku. Dlaczego w różnym? Tu właśnie objawia się istota koncepcji Gasseta. Podstawowymi atrybutami pokolenia są wspólne ludziom w nim żyjących przestrzeń i czas. Pokolenie jest więc rodzajem mody, integralnym sposobem istnienia jednostek piętnującym ich życie „niezniszczalnym znamieniem”. Rówieśnicy cechują się zatem tożsamością przeznaczenia przejawiającą się w jedności stylu życia. Dlatego też Gasset może twierdzić, że współistniejemy jedynie z rówieśnikami, pozostali są zaś nam jedynie współcześni. Oznacza to, że w każdym pojedynczym dzisiaj istnieje wiele pokoleń obok siebie.

Życie jest czasem - jak nam to unaocznił Dilthey, a dzisiaj powtarza Heidegger - i nie wyimaginowanym czasem kosmicznym, a przez to i nieskończonym, lecz czasem określonym, czasem, który się kończy, który jest czasem prawdziwym, czasem nieodwracalnym. Dlatego człowiek ma wiek. Wiek to przybywanie człowieka zawsze w pewnym odcinku jego znikomego czasu - to być początkiem czasu życiowego, być wznoszeniem się ku jego połowie, być jego środkiem, być zbliżaniem się do jego kresu - czy, jak zwykło się mówić, być dzieckiem, młodym, dojrzałym lub starcem. Oznacza to jednak, że każda aktualność dziejowa, każde »dzisiaj« w rzeczywistości zamyka w sobie trzy różne czasy, trzy różne »dzisiaj«; innymi słowy, że czas teraźniejszy zasobny jest $\mathrm{w}$ trzy wielkie życiowe miary, które umieszczone w nim, chcąc nie chcąc, współżyją ze sobą nawzajem uwikłane i jako różne siłą rzeczy pozostają wobec siebie w postawie zasadniczej niechęci. »Dzisiaj« to dla jednego dwadzieścia lat, dla innych - czterdzieści, dla jeszcze innych - sześćdziesiąt; i to właśnie,

\footnotetext{
7 Tamże, s. 28.
} 
co będąc trzema tak różnymi sposobami życia musi być tym samym »dzisiaj«, wywołuje dynamiczny dramatyzm, konflikt i spór, stanowiące tło historycznej materii, każdego aktualnego współżycia [...] Wszyscy jesteśmy sobie współcześni, żyjemy w tym samym czasie i atmosferze, ale na różny sposób przyczyniamy się do ich kształtowania. Współistniejemy tylko z rówieśnikami [...] Gdybyśmy jako ludzie sobie współcześni byli wszyscy rówieśnikami, dzieje by znieruchomiały, skamieniały, zatrzymały się w ostatecznym geście, bez możliwości jakiejkolwiek radykalnej odmiany ${ }^{8}$.

Jasne staje się teraz, dlaczego biegu historii nie mogą tworzyć jedynie rówieśnicy, dodajmy przy tym: rówieśnicy w sensie witalnym, nie zaś matematycznym. Wiek jest bowiem pewną sferą dat, w której mieszczą się ludzie urodzeni w pewnym przedziale lat, dla Gasseta przedział ten wynosi lat piętnaście. Powielając, świadomie bądź nie, wschodni model podziału dojrzałości człowieka na etapy: dziecka, wojownika, ojca i mędrca, autor Medytacji o Don Kichocie dzieli ludzkie życie na pięć okresów. Licząc po piętnaście lat są to okresy: dzieciństwa, młodości, inicjacji, panowania i starości. Pierwszy i ostatni, rzecz oczywista, wyłączone są niemal zupełnie z dziejowości, nie przyczyniają się bowiem do jej postępu. Pewnym wyjątkiem są rady starców, $\mathrm{w}$ wielu kulturach służące młodym cennym doświadczeniem. W pewnym sensie znajdują się oni już za dziejowością, tak jak dzieci jeszcze przed. Nieco lepiej wygląda sprawa $\mathrm{z}$ etapem młodości, który według Gasseta zasadza się na życiu jednostki dla niej samej, na dopiero „bawieniu się w życie” i w zainteresowanie się nim. W tym okresie człowiek jedynie szuka pretekstu do zajmowania się sobą. Natomiast przekraczając magiczny wiek lat trzydziestu, zyskujemy prawdziwą możliwość reagowania na świat na własny użytek. Nie powielamy już ducha epoki, przeciwnie, będąc coraz bardziej świadomymi źródeł własnej wiedzy i jej aktualnego stanu, zaczynamy tworzyć własne pojęcia i teorie dotyczące atakowanego przez nas zastanego świata. Zdobyta wcześniej wiedza, teraz już zweryfikowana, będąca coraz częściej naszą drugą naturą, pozwala nam podważać światy ludzi panujących, światy obowiązujące, podtrzymywane przez czterdziestopięciolatków i ich starszych kolegów po fachu. To oni bowiem odpowiadają za „obecny” stan ludzkiej wiedzy i to oni bronią go przed atakiem dopiero urządzającej się w świecie młodości.

Trzydziestokilkuletni, a więc wciąż jeszcze młody człowiek, podważa zastany porządek rzeczy. Bez znaczenia jest przy tym, czy robi to w obszarze nauki, techniki, sztuki, filozofii czy religii. Istotne jest natomiast to, że go ata-

${ }^{8}$ Tamże, s. 30. 
kuje, bo mu nie pasuje do własnej rzeczywistości. Każda zmiana jest modyfikacją zastanego świata. Atakujący i dobrze okopani broniący się odpowiadają zatem za tworzenie dziejowej rzeczywistości. To ludzie z tych dwóch etapów dojrzałości przyczyniają się do rozwoju cywilizacji i samej historii. Pierwsi przez swe dopiero co odkryte idee i zalążki oryginalnych koncepcji, drudzy przez bazowanie na swych pozbawionych już młodzieńczej inspiracji gotowych ideologiach szlifowanych nieustannie z taką pieczołowitością. Dzięki temu, że oba etapy współwystępują, zderzają się i w walce, we wzajemnym ścieraniu swych poglądów, wypracowują postęp. Oczywiście nie musi on zmierzać jedynie w jakimś pozytywnym kierunku, wszak to, co nowe, to, co wypiera to, co dziś obecne, a jutro już tylko przestarzałe, wcale nie musi być lepsze. Po prostu lepiej odpowiada młodszym, a więc i służy im lepiej. Czy zabrną w ślepą uliczkę dogmatów, czy rozwiną nowy wartościowy nurt filozoficzny, i tak przyjdą następcy, którzy zweryfikują to i poddadzą krytyce. I albo wcześniejsza myśl utrzyma się kosztem kilku modyfikacji, czasem zresztą nawet twórczych, przydatnych i ożywczych, albo zniknie, jak zniknęło już wiele takich ślepych uliczek ludzkich idei. Pewnego rodzaju pocieszeniem dla osób z etapu panowania i rządzenia z pewnością jest fakt, że gdy oni odejdą w wiek starczy, ich miejsce zajmą następni „odpowiedzialni”, którzy również w nierównej walce z czasem odejdą.

Wiedza kumuluje się w historii, w duchu czasu lub epoki, w przekonaniach anonimowego podmiotu, tworząc $\mathrm{w}$ ten sposób kulturę. Każdy człowiek, wrastając w nią, tworzy z niej własny horyzont i oazę spokoju. Oczywiście dzieje się tak do momentu, w którym zaczyn nas ona uwierać. Gasset zauważa, że nie dla wszystkich jednak jest ona aż tak niewygodna. Znajdą się i tacy, którzy w ramach własnego universum nie będą stawiać sensownych pytań i poszukiwać autentycznych problemów życiowych. Nie sięgając wówczas do własnych mocy twórczych i pokładów sił witalnych, lecz do rezerwuaru gotowych rozwiązań, jakim jest kultura9 ${ }^{9}$, zatracają się w niej, uspołeczniają i tracą

\footnotetext{
${ }^{9}$ Por. następujący fragment: „Kultura stanowi jedynie interpretację, jaką człowiek nadaje swojemu życiu, serię mniej lub bardziej zadowalających rozwiązań, jakie człowiek wymyśla, aby zaradzić swoim problemom i życiowym koniecznościom [...] Rozwiązania, które powstały z autentycznych konieczności, są rozwiązaniami autentycznymi, są ideami, ocenami, natchnieniami, stylami myślenia, sztuki, prawa, jakie rzeczywiście wypływają z radykalnej głębi człowieka, w tym stopniu, w jakim był on naprawdę w momencie zapoczątkowującym jakąś kulturę. Jednakże utworzenie repertuaru zasad i kulturowych norm pociąga za sobą pewną niedogodność zasadniczą i - ściśle mówiąc - ostateczną. Jeżeli bowiem powstaje prawdziwe rozwiązanie, skoro już »tu jest«, następne pokolenia nie muszą go wymyślać, a jedynie
} 
autentyczność własnego życia. Nie mierząc się ze światem własnymi siłami, zafałszowują samych siebie, wypierają się siebie.

Gasset, analizując ludzkie życie, podkreśla często naszą w nim samotność i potrzebę bycia autentycznym, zauważą przy tym, że:

Mój problem, nurtujący mnie niepokój - to moje sprawy i na razie tylko moje. To ja muszę wpaść na myśl, która rozwiąże problem i uleczy bądź złagodzi mój niepokój. To ja muszę w każdej chwili decydować o tym, co za moment zrobię, i niepodobna, aby ktokolwiek zrobił to za mnie, aby mnie w tym zastąpił. Aby móc jednakże rozstrzygać o swojej egzystencji, o działaniu czy niedziałaniu, muszę rozporządzać pewnym repertuarem przekonań o świecie, repertuarem mniemań. Muszę je żywić i rzeczywiście się do nich przekonać. Tym właśnie jest życie - przydarza się ono tylko mnie i w ostateczności tylko ja muszę je realizować [...] Fakt, że na jakiś temat mam swoje zdanie, oznacza jedynie, że wiem, czego mam się trzymać, czyli że ustaliłem swoja pozycję wobec danej rzeczy. Miewam przeróżne możliwe sądy na dany temat, muszę jednak pogodzić się z sobą, aby wiedzieć, który z nich mnie przekonuje, a więc który jest moją prawdziwą opinią. I tak ta ukuta przeze mnie opinia, którą opieram na tym, co jest dla mnie oczywiste, jest naprawdę moją opinią, ponieważ mieści w sobie to, co rzeczywiście i autentycznie myślę na dany temat, a myśląc tak, pozostaję tym samym w zgodzie z sobą, jestem sobą. Toteż ciąg czynów, sposobów postępowania, życia, jaki owo autentyczne mniemanie rodzi i motywuje, będzie moim autentycznym życiem, moim autentycznym bytem ${ }^{10}$.

Autentyczność naszego życia możliwa jest oczywiście tylko wówczas, gdy będą przed nami stawać istotne dla nas problemy. Tylko mierząc się z nimi możemy wykazać się i stać się sobą w sposób pełnowartościowy. Zdaniem Gasseta zarówno ludzkie życie w „okolicznościach”, jak i sam fakt naszego zmagania się z nimi oraz istnienia potrzeby zbudowania bezpiecznej przystani, zawsze będą występowały w ludzkim życiu. Nie są to zjawiska, które mogą nagle ustać, to nieusuwalne elementy naszej ludzkiej natury.

przyjąć i rozwijać. Otóż takie przejmowanie, które oszczędza wysiłku tworzenia, jest o tyle niekorzystne, że skłania do życiowej bierności. Człowiek, który przejmuje jakąś ideę, stara się oszczędzić sobie trudu przemyślenia jej i odtworzenia w sobie samym [...] Otóż człowiek, który jest już spadkobiercą pewnego systemu kulturowego, stopniowo, pokolenie po pokoleniu, przyzwyczaja się do niesięgania po podstawowe problemy, do nieodczuwania konieczności, jakie składają się na jego życie, z drugiej zaś strony do korzystania z myślowych form - idei, ocen, natchnień - które nie są dlań oczywiste, ponieważ nie zrodziły się w głębi jego własnej autentyczności." (J. O. Gasset, Wokół Galileusza, s. 68).

${ }^{10}$ J. O. Gasset, Wokół Galileusza, s. 64. 
Oczywiste jest, że przywołując jedynie fragmenty koncepcji hiszpańskiego filozofa pomijamy takie jej elementy, jak chociażby kryzys, pojawiający się, gdy upadają stare ideały a nowe jeszcze się nie zjawiły. Nie możemy zatem dostrzec całości jego poglądów a więc i pełniej perspektywy, z której oglądany jest przezeń człowiek. Wystarcza to jednak, aby wskazać na istotne słabości historiozofii Fukuyamy. Koniec historii nie nastąpi. Wskazana przez Gasseta idea pokolenia wiąże się z ludzką potrzebą zakorzenienia się w świecie poprzez stałe podważanie jego aktualniej postaci i stworzenie własnego universum. Ludzkość nie osiągnie więc etapu, w którym zaprzestanie tego podważania, bo nagle osiągnie to, co upragnione i idealne. Człowiek zawsze będzie reagował na zastany świat i zawsze będzie go zmieniał. Fukuyama jest daleki od takich wniosków. W jego wizji dziejów człowiek osiąga jednak etap, na którym zatrzymuje się i realizuje bez zbędnej już wówczas rywalizacji. W pewnym sensie wystarczyć miałaby mu jedynie niemal odgórnie przypisana równość z wszystkim innymi ludźmi, sam zaś thymos podlegałby sublimacji w niegroźnych dla demokracji liberalnej formach. Czy zatem ten pozbawiony ikry człowiek, dbający bardziej o prestiż i zaspokojenie konsumpcyjnych potrzeb niż o duchowy rozwój i refleksję nad kondycją współistniejącego z nim człowieka, nie przypomina tych uspołecznionych i nieautentycznych ludzi opisanych przez Gasseta? Z pewnością zachodzi tu pewne podobieństwo.

W Wokót Galileusza Ortega y Gasset nie wskazuje jednak na takie determinanty ludzkiej natury, lub może lepiej, na drzemiące w niej siły napędzające bieg historii jak thymos. Dlatego też należy się teraz przyjrzeć, na ile on sam w swych odmiennych formach może przyczynić się do tego, że w różnych częściach świata, różni ludzie ze swymi odmiennymi kuchniami, systemami szkolnictwa, gospodarkami i religiami, będą zmierzać ku kapitalistycznej demokracji liberalnej. Czy rzeczywiście thymos jest tak potężny, czy gdy już doprowadzi ludzkość do pożądanego i opiewanego tak bardzo przez Fukuyamę ustroju, wyciszy się i przestanie na nas oddziaływać? Czy aby na pewno można go sublimować w etos pracy, konsumpcję i zawody sportowe? Czy w ogóle metodologiczny idealizm Fukuyamy, sprowadzenie niemal wszystkiego do jednego prostego czynnika, którym jest potrzeba uznania, nie jest zbyt wielkim uproszczeniem? W konfrontacji z koncepcją Gasseta wydaje się, że wizja zarysowana w Końcu historii nie jest jednak do końca przemyślana.

Fukuyama w swych pracach powołuje się na platońskie źródła pojęcia thymos. Wydaje się jednak, że pojęcie to było już znane wcześniej, możemy 
odnaleźć je choćby u Homera ${ }^{11}$. Jednak zaprzęgnięcie jej do platońskiego rydwanu jako białego konia pozwala $\mathrm{z}$ pewnością najlepiej określić jej istotę i rolę w całej ludzkiej psychiczności. Z uwag Fukuyamy dotyczących filozofii Platona zawartych w Ostatnim człowieku można wnosić, że przedstawiona przez greckiego filozofa koncepcja duszy miała duży wpływ na kształtowanie się poglądów Fukuyamy.

Platon uważał - czytamy na końcowych stronach Ostatniego człowieka - że thymos, jakkolwiek stanowi oparcie dla cnót, samo w sobie nie jest ani dobre, ani złe, lecz musi zostać wyszkolone, aby służyło dobru wspólnemu. Innymi słowy, należy sprawić, aby thymos było rządzone przez rozum i stało się sprzymierzeńcem pożądania. Państwo sprawiedliwe to takie, w którym wszystkie trzy części duszy są zaspokojone i zrównoważone pod nadzorem rozumu. Najlepszy ustrój jest zatem niezwykle trudny do realizacji, ponieważ musi zaspokoić równocześnie całego człowieka, jego rozum, pożądanie i thymos. Jeżeli rzeczywiste ustroje nie są w stanie całkowicie zaspokoić człowieka, najlepszy ustrój dostarcza wzorca, według którego możemy oceniać istniejące. Najlepszy ustrój, powtórzmy, to taki, który najlepiej zaspokaja wszystkie trzy części duszy równocześnie ${ }^{12}$.

${ }^{11}$ Por. Ch. A. Faraone, Thumos as Masculine Ideal and Social Pathology in Ancient Greek Magical Spells, [w:] Ancient Anger: Perspectives from Homer to Galen, red. S. Braund, G. W. Most, Cambridge University Press, 2003, a także J. Bremmer, The Early Greek Concept of the Soul, Princeton University Press, 1983. Bardzo interesujące uwagi na temat związków duszy i ciała, a także ucieleśniania uczuć znaleźć można w G. Böhmego, Antropologii filozoficznej. W rozdziale XVII czytamy m.in., że „proces antropologicznego przełomu zachodzący między Homerem i Platonem można objaśnić jako odkrywanie duszy będące jednocześnie wypieraniem ludzkiego ciała. Proces ten Schmitz nazywa »introjekcją uczuć«. Pierwotnie człowiek wystawiony był mianowicie na działanie uczuć jako potęg ogarniających go z zewnątrz. Uczuć jako potęg nastroju - stanowiących możliwą interpretację greckiego świata bogów człowiek homerycki doznawał bezpośrednio, cieleśnie, w sercu, w piersi, we wnętrznościach. Żeby znaleźć przeciwko temu jakiś punkt oporu, człowiek wytworzył pewną autonomiczną instancję wewnętrzną - duszę. Dzięki niej, w istocie nieumiejscowionej, udało mu uwolnić się od emocji cielesnych, przekształcić afektywne ogarnianie przez uczucia w afekty duszy. Od tej pory, a w pełnym wymiarze od epoki poplatońskiej, uczucia jako takie były postrzegane tylko jako afekty duszy, jako jej stany, a ich nastrojowa realność jako potęg, które z zewnątrz ogarniają człowieka, zaniknęła, została wyparta i zapomniana." (G. Böhme, Antropologia filozoficzna. Ujęcie pragmatyczne, tłum. P. Domański, Warszawa 1998, s. 219). Oczywiście jednymi z tych zewnętrznych potęg były Thymos i Eros. Szerzej na ten temat patrz: H. Schmitz, System der Philosophie, Bonn 1964-1980, zwłaszcza t. I, 1. Der Leib i t. III, 2, Der Gefühlsraum.

${ }^{12}$ F. Fukuyama, Ostatni człowiek, s. 189. 
Oczywiście zdaniem amerykańskiego politologa tym najlepszym ustrojem jest demokracja liberalna, choć sam Platon, jak wiemy, nie był zwolennikiem demokracji. Jego zdaniem najlepsze państwo to takie, które jest sprawiedliwe, czyli takie, w którym każdy człowiek wie, co ma robić i tylko temu się poświęca. Struktura tej idealnej rzeczypospolitej miała odzwierciedlać strukturę ludzkiej duszy. I tak jak w tej ostatniej Platon wyróżniał trzy elementy składowe: duszę rozumną, dusze popędliwą (thymos) i duszę pożądliwą (eros), tak i w państwie widział miejsce dla trzech kast: rządzącej, wojskowej i rzemieślniczej. Ta trychotomia odpowiada trzem najważniejszym ideom: prawdzie, dobru i pięknu. Dlatego też cnotą rządzących krajem filozofów jest mądrość, strzegących ustalonego przez nich porządku wojskowych jest męstwo, dla rzemieślników zaś odpowiedzialnych za zaspokajanie potrzeb wyższych kast cnotą taką jest rozwaga, czyli panowanie nad sobą. Platoński projekt państwa zakład przy tym jednak, że dopiero właściwa współpraca wszystkich trzech grup pozwoli dzięki powstałej wówczas harmonii na osiągnięcie przez to państwo statusu sprawiedliwego. Sprawiedliwość ta stanowi o dzielności państwa, którą można osiągnąć tylko poprzez właściwe rozdzielenie przywilejów i obowiązków poszczególnym ludziom i przymuszenie ich do wykonywania właściwych ich urodzeniu prac $^{13}$. Przekładając te rozważania na odzwierciedlającą państwowy porządek duszę, należy również przyjąć, że i w jej obrębie części lepszej (duszy rozumnej) podporządkowane są części gorsze (dusze popędliwa i pożądliwa). Mówiąc inaczej, rozum dysponuje nadrzędną władzą wobec naszego temperamentu i namiętności.

Odwołując się do odpowiedniości duszy i państwa, Platon kreśli między innymi wizję wojskowych lub strażników państwa uosabiających popędliwą część duszy, a więc thymos. W świetle jego koncepcji jest on jednak pojmowany dość szeroko, bo nie zostaje zawężony, jak w ujęciu Fukuyamy, do pojęcia potrzeby uznania, ale skupia w sobie całą gamę afektów. Znajdziemy tu bowiem, jak słusznie zauważa Władysław Witwicki, to, co „my nazywamy inaczej zapalczywością, szlachetnym zapałem, pasją, nawet skłonnością do gniewu, czasem energią"14. Głównie jednak thymos oznacza żywy tempera-

\footnotetext{
${ }^{13}$ Nie wchodząc w szczegóły, pragnę jedynie przypomnieć, że platońskie państwo wymagało dla swego sprawnego działania wielu socjotechnicznych zabiegów i sztuczek. W imię szczytnych ideałów kasta rządzących miała mieć możliwość sterowania i manipulowania ludem, przebierania w nim jak w ulęgałkach i wybierania osób o określonych predyspozycjach fizycznoumysłowych do właściwych ich zdolnościom zadań. Miejmy nadzieję, że w swoich kolejnych pracach Fukuyama nie pójdzie aż tak daleko.

${ }^{14}$ Platon, Państwo, tłum. W. Witwicki, Kęty 2006, s. 69.
} 
ment lub takież usposobienie, rzadziej gniew, poruszenie czy właśnie przywoływane przez Fukuyamę pragnienie uznania. Zresztą widać w Państwie, że thymos musi w sobie łączyć elementy zarówno tej żywości temperamentu, jak i pewnej łagodności w stosunku do pozostałych obywateli rzeczypospolitej. Platon porównuje nawet strażnika do psa, który szczerzy zęby na obcych, łasi się zaś i przymila do domowników. W dodatku cechę tę tłumaczy wpływem umiłowania mądrości, gdyż garnąć się do swoich to tyle samo, co cieszyć się na widok tych, których znam a więc i tego, co mi bliskie. Psie umiłowanie pana ma więc $w$ tym pokrętnym rozumowaniu znaczyć tyle, co umiłowanie wiedzy, a więc i mądrości. Strażnik w państwie również ma miłować, choć tym razem nie rządzących, lecz ich prawa, i to w ich świetle może dopiero właściwie postępować. Jeśli zaś od małego dziecko będzie dobrze kształcone i wychowywane za pomocą muzyki i gimnastyki, a zaszczepione przy tym zostanie mu umiłowanie mądrości, wówczas to będzie ono mogło zostać dobrym strażnikiem. Jego temperament i umiłowanie wiedzy będzie trzeba jednak nadal kształcić, by w tym dwugłosie razem brzmiąc czysto podnosiły wartość jednostki. Rzecz oczywista, wartość ta ma przede wszystkim przejawiać się w przydatności obywatela dla państwa. Dlatego też kasta wojskowych pozbawiona zostaje, choć nie w pełni, takich przywilejów, jak małżeństwo, wynagrodzenie i inne korzyści materialne. Nic nie powinno odciągać ich od powinności, jaką jest służba własnemu krajowi. Żyjąc w celibacie i pracując niemal bez żadnego wynagrodzenia, funkcjonują jak w zakonie, bacząc jedynie na przestrzeganie przez innych praw. Nadzorują więc słabszych (rzemieślników), a podlegają silniejszym (rządzącym). Wracając do trójpodziału duszy, należałoby zatem powiedzieć, że obowiązkiem temperamentu jest podleganie rozumowi i wspólne z nim poskramianie namiętności. Relację tę doskonale Platon oddał w metaforze rydwanów z drugiej mowy Sokratesa w Faidrosie.

Przypomnijmy, że odmalowana tam dusza składa się z woźnicy (rozumu) powożącego rydwanem zaprzęgniętym w dwa konie: białego (thymosa) symbolizującego temperament i czarnego (erosa) symbolizującego namiętności. Przy tej okazji Platon zestawia dwa rodzaje rydwanów; jedne - boskiej natury, prowadzone przez samych bogów, mkną niezwykle równo po nieboskłonie, drugie zaś - ludzkie - pędzące za nimi w ich orszakach, nie są już tak szybkie, sprawne i zwrotne, a oba konie nie dają się już tak równo prowadzić. Platon w tej metaforze doskonale oddaje sytuację człowieka uwikłanego w okoliczności, a że Faidros jest dialogiem o pięknie i miłości, to i opis duszy odnosi się do sytuacji zakochiwania się. Nie ma wówczas mowy o równym 
prowadzeniu rydwanu. Każdy koń rwie bowiem w swoją stronę, a biedny woźnica może tylko pokrzykiwać i smagać batem. W pojedynkę z pewnością nie opanowałby tej rozwydrzonej pary. Rozum nie pozostaje jednak osamotniony, z pomocą przychodzi mu bowiem temperament. Biały koń wydaje się lepiej służyć woźnicy, a już na pewno nie śpieszno mu zmierzać drogą obraną przez współtowarzysza przy dyszlu. Kiedy czarny koń pobudzony jest widokiem ukochanej osoby, prze ku niej, rozszerzają mu się chrapy, krew burzy się w żyłach, rży, lędźwie dają znać o sobie. To chuć i pożądanie, koń zaślepiony silną namiętnością nie patrzy już na drogę, nie groźne mu kamienie i wyboje, zmierza do celu, do ukochanej osoby. A biały koń w tym czasie jest jakby porażony: lęk go ogarnia, gniew o to, dokąd obaj zmierzają. Wspiera woźnicę i razem próbują opanować rwącego do przodu wierzchowca. Dlaczego tak się dzieje? Biały koń jest po prostu dobrze ułożony, od początku był właściwie prowadzony, wie, jak poruszać się w zaprzęgu, wie co to zakazy, wie co to przyzwoitość i obowiązek. A to, co widzi, nie przypomina mu tego, co prawe i szlachetne. Tak jak strażnik przestrzega praw w państwie, tak on w zaprzęgu opowiada za służbę woźnicy.

Otóż z tych koni jeden — pisze Platon — jest dobry, drugi zaś nie [...] ten z nich, który się znajduje po lepszej stronie, ma postać prostą, ukształtowaną, podniesiony kark, chrapy zaokrąglone, białą maść, czarne oko, dbały o dobre imię $\mathrm{w}$ połączeniu $\mathrm{z}$ panowaniem nad sobą i poczuciem godności, zwolennik słusznej sławy, nie wymagający bata, prowadzony jedynie rozkazem i słowem. Ten drugi zaś przeciwnie: jest sękaty, duży, byle jako sklecony, twardego karku, krępy, chrapy zadarte, czarna sierść, błyskające, nabiegłe krwią oczy, skłonny do buty i chełpliwości, wokół uszu kudłaty, tępy, uderzeniu bata wraz z ościeniem, ledwo ulega. Gdy więc woźnica na widok przedmiotu miłości, rozpalającego całą duszę uczuciem, napełnia się żądłami łaskotania i tęsknoty, wówczas ten z koni, który ulega woźnicy, zawsze, i wtedy również, pod wpływem czci poskramia siebie, aby nie rzucić się na umiłowanego. Drugi zaś nie robi sobie już nic ani z ościenia, ani z bicza woźnicy, lecz krnąbrny pędzi gwałtem, i robiąc wszystko na przekór drugiemu z zaprzęgu i woźnicy zmusza, by iść ku umiłowanemu i przypomnieć o rozkoszach Afrodyty. Ci dwaj wprawdzie z początku oburzeni sprzeciwiają się, że się ich zmusza do okropnego bezprawia. W końcu jednak, gdy zło nie ma końca, dając się prowadzić idą za nim, ustępują i zgadzają się uczynić to, czego się domagano. I zbliżają się do niego i widzą jaśniejące oblicze umiłowanego [...] Widząc zaś [go - przyp. moje] doznaje lęku i przejęty bojaźnią przegina się wstecz, a jednocześnie czuje się zmuszony szarpnąć lejcami wstecz tak mocno, że oba konie przysiadają na zadach, 
ku zadowoleniu jednego, gdyż ten nie ciągnie w przeciwną stronę, buntowi zaś drugiego, który jest bardzo nierad. Gdy [zaprzęg] zatrzymał się z dala, jednemu z powodu wstydu i lęku oblewa się cała dusza potem, drugi zaś, pozbywszy się bólu, którego doznał od wędzidła i od zawodu, ledwo ochłonąwszy wymyśla w gniewie, rzucając mnóstwo obelg na woźnicę i wspólnika w zaprzęgu, że są nasiąknięci tchórzostwem i bojaźliwością co do postanowienia i umowy. A gdy znów nie chcą pójść za jego wolą, on pod przymusem ledwo ustępuje na ich prośbę o ponowną zwłokę ${ }^{15}$.

Tak odmalowuje Platon znaną powszechnie scenę z zakochanym w roli głównej. Widać $\mathrm{z}$ niej dobrze jak właściwie kształcone i rozwijane thymos służy człowiekowi. Podporządkowane rozumnemu wysiłkowi, umożliwia zachowanie dumy, a jednocześnie pozwala zrealizować ludzkie potrzeby. Nie jest bowiem powiedziane, że thymos pozbawia nas przyjemności. Przeciwnie, jedynie przestrzega nas byśmy dobrego imienia nie stracili i panowali nad sobą. Problem natomiast pojawia się wówczas, gdy temperament nasz nie daje sobą powodować, gdy biały koń z czarnym mkną przez życie razem, gdy thymos sprzymierza się z erosem i obaj zatracają się w przyjemnościach: zgubią wówczas i woźnicę, i siebie.

Odnieśmy zatem Platońskie pojęcie thymos do przywoływanego przez Fukuyamę pragnienia uznania. Z pewnością odnajdziemy w obu koncepcjach wiele wspólnego. Kochając kogoś, lub nawet tylko przeglądając się w oczach tej, która nam się podoba, pragniemy przecież dostrzec uznanie. Lubimy być doceniani, dobrze postrzegani i jak to się zwykło mówić - dobrze wypaść. Nic w tym złego. Ot, zwykłe zaspokojenie próżności czy właśnie potrzeby uznania. Rzecz jednak w tym, byśmy dumę odczuwali z wyższych pobudek niż tylko takich, jak uroda czy status materialny. Bo choć i te atrybuty pozwalają cieszyć się uznaniem innych, z pewnością jednak Platon nie miał ich na myśli, kreśląc sylwetkę miłującego i umiłowanego. Wszak nie możemy zapominać, że strażnik w Platońskim państwie jest ubogi i żyje w celibacie, że służy i przestrzega praw, że wreszcie jest dumny z tego, że dzięki niemu państwo może być sprawiedliwe, a on jest jego ważną częścią. Poza tym nie pozostaje sam, potrzebuje innych: dopiero wszystkie części duszy, odpowiednio kształcone i współpracujące, osiągną harmonię, dzielność i sprawiedliwość. W pojedynkę zarówno rozum, jak i thymos i eros zawsze doprowadzą nas na manowce. Właśnie o tej potrzebie zharmonizowania władz duszy zdaje się zapominać Fukuyama. Nie dość więc, że największą rolę w napędzaniu

${ }^{15}$ Platon, Faidros, tłum. L. Regner, Warszawa 1993, s. 38. 
dziejowości przypisuje on właśnie duszy popędliwej, to pozostawia ją niemal osamotnioną na tym placu boju. Wspomina co prawda o potrzebie jej kształcenia, lecz zakłada od razu, że można ją sublimować w działaniach gospodarczych i w etosie pracy. Nie twierdzi przy tym, że to jego pomysł, lecz, że proces ten po prostu zaszedł w nowożytności wraz z powstaniem pierwszych projektów państwowości wyrosłej ze stanu natury.

Zalążki tego procesu Fukuyama dostrzega już w doktrynie Hobbesa, który jego zdaniem potęgę thymos przyoblekł w szaty ludzkiej potrzeby samozachowania i próżności:

U Hobbesa stan wojny nie bierze się jednak wyłącznie z dążenia do samozachowania - podkreśla - lecz z tego, że instynkt samozachowawczy współistnieje z próżnością czy pragnieniem uznania. Hobbes powiedziałby, że gdyby nie było ludzi, którzy chcą narzucić swe poglądy innym, szczególnie fanatyków religijnych, to pradziejowy stan wojny nigdy by się nie narodził. Sam instynkt samozachowawczy nie stanowi wystarczającego wytłumaczenia wojny wszystkich ze wszystkimi ${ }^{16}$.

Pytanie tylko, czy coś poprzedzało ten pradziejowy stan wojny, a jeśli tak to, co to było. Wszak koncepcja stanu natury jako swoiste, i skądinąd jedynie hipotetyczne, wyjaśnienia początków dziejowości miały właśnie opisać stan pierwotny. Oczywiście Rousseau mógłby powiedzieć, że zanim nastał czas wojny wszystkich ze wszystkimi, człowiekowi działo się całkiem dobrze i stan ten mógłby trwać długo, gdyby nie coraz większa liczba ludzi i coraz częstsze kontakty między nimi. Przyjrzyjmy się wnikliwiej poglądom Hobbesa w tej materii.

Rzeczywiście można uznać go za jednego z pierwszych twórców modelu państwowości wyłaniającej się ze stanu natury. Czy jednak Fukuyama właściwie interpretuje podstawy towarzyszącej mu wojny wszystkich ze wszystkimi? Wydaje się, że najciekawsza i najpłodniejsza interpretacja tej części rozważań Hobbesa prowadzi do uznania, że wojna ta jest stałym zagrożeniem, możliwością, która w każdej chwili, gdy tylko zabraknie suwerennej i skutecznej władzy, może się zrealizować. Ten wszechogarniający konflikt nie ma swego początku, lecz w zasadzie sam jest właściwością stanu natury. Żyjąc w nim, ludzie są sobie wystarczająco równi, aby różnice między nimi nie przekreślały szans jednego na osiągnięcie jakiejś korzyści kosztem drugiego. W tak szeroko pojmowanej korzyści mieści się oczywiście zarówno realizacja

${ }^{16}$ F. Fukuyama, Ostatni człowiek, s. 85. 
potrzeby samozachowania, jak i prawo do zaspokojenia potrzeb związanych $\mathrm{z}$ wygodnym życiem.

To z tego stanu naturalnej różności należałoby wyprowadzić właściwą ludzkiej naturze obawę o własne życie i godne warunki bytowe. W tym miejscu podkreślmy, że chodzi właśnie o godne warunki bytowe, a nie o przedmioty zbytku i luksusu. W rzeczywistości Hobbes wcale nie pojmował ludzkiej natury jednostronnie negatywnie. $\mathrm{Z}$ wielu fragmentów Lewiatana wyłania się wręcz przeciwny obraz. Hobbes bowiem odmalował człowieka jako istotę zdolną do życzliwości, do niesienia pomocy innym, miłości i wyższych uczuć. Wskazując zaś na możliwe negatywne cechy, takie jak chociażby ta przywoływana przez Fukuyamę próżność, próbuje własne rozważania, „wnioski oparte na uczuciach”, uczynić bardziej wiarygodnymi, prawdopodobnymi i lepiej uzasadniającymi ogólne tezy Lewiatana. Gdy Hobbes chce wykazać jak bardzo potrzebny jest ludziom suweren, do tego by ustanowić pokój i prawa dla wszystkich, musi podać psychologiczne determinanty ludzkiej natury popychające go do działań wymagających poskromienia. Przykładowo, wskazując na ludzką próżność jako jedną z przyczyn zaprowadzenia pokoju, która dopiero wówczas mogłaby zostać zaspokojona, zmuszony jest przyjąć, że cecha ta może dotyczyć wszystkich ludzi. A przecież większości z nich wystarczy zaspokojenie podstawowych potrzeb wraz z niewielką nawiązką będącą namiastką luksusu. Nie każdy przecież musi w nieposkromiony sposób dążyć do dóbr materialnych, sławy lub poklasku. Jednak z perspektywy jednostki sprawa wygląda nieco inaczej. Cele innych osób nie są nam znane, możemy więc zakładać, że mogą być one również i skrajnie odmienne od naszych. I choć wówczas sami mamy siebie za osoby przyzwoite, to o sąsiadach potrafimy myśleć jak o ostatnich oszustach czy próżniakach. To samo dotyczy próżności i potrzeby uznania. Nie są one bowiem tak silnie zakorzenione w ludzkiej naturze jak popęd samozachowawczy, choć i one w mniejszym lub większym stopniu dają znać o sobie u każdego z nas. Natomiast możliwość, że w stanie wojny, u niektórych jednostek osiągną niebotyczne rozmiary, każe myśleć nam o nich jako o stałym zagrożeniu - leży w naszym najlepiej pojętym interesie własnym. Gdy choć garstka ludzi się zbroi czy gromadzi więcej jakichś dóbr, reszta musi robić to samo. Nie robiąc tego, może, i to „może” należałoby podkreślić, grozić nam, że albo przegramy z orężem silniejszego wroga, albo zostaniemy z niczym i umrzemy z głodu. Bierzemy więc pod uwagę już samą możliwość wystąpienia zagrożenia. Jeżeli bowiem jest ono choć tylko trochę możliwe, to jak daleko jest droga do tego byśmy uwierzyli, że jest ono realne. Podobne uwagi znaleźć możemy u Johna Rawl- 
sa, który analizując stan natury w koncepcji Hobbesa, podkreśla znamienną dla argumentacji autora Lewiatana cechę, pomijaną często przez interpretatorów jego poglądów. Mianowicie zauważa on, że Hobbes odnosi się do ludzi całkiem normalnych, przeciętnych, umiarkowanych w swych poglądach i zachowaniach, dążeniach i pragnieniach, a nie do ekstremalnych monstrów o egoistycznej naturze:

Znaczenie argumentacji Hobbesa polega po części na fakcie, że opiera się ona na całkiem wiarygodnych przesłankach dotyczących normalnych warunków życia ludzkiego. Na przykład nie zakłada on, że pycha i próżność faktycznie skłaniają wszystkich do dążenia do dominacji nad innymi. Byłoby to wątpliwe założenie. Doprowadziłoby go ono do wniosków, do których dochodzi, ale o wiele za łatwo. Tym, co czyni jego argumentację przerażającą oraz nadaje jej znaczenie i dramatyczną moc, jest to, że sądzi on, iż normalni, nawet całkiem mili ludzie mogą znaleźć się w tego rodzaju sytuacji, a ona zdegeneruje się w stan wojny. Zatraca się znaczenie tego ujęcia, jeśli kładzie się nadmierny nacisk na żądzę mocy i dominacji. Siła tezy Hobbesa i powodem, dla którego jest ona tak znaczacym osiągnięciem (nawet jeśli Hobbes nie formułuje jej w staranny i ścisły sposób) jest to, że jej przesłanki opierają się wyłącznie na normalnych i mniej lub bardziej stałych warunkach życia ludzkiego, jakie całkiem prawdopodobnie mogłyby istnieć w stanie natury. Problem jest następujący: nie musimy być potworami, żeby znaleźć się w poważnych opałach. Pamiętajmy, że psychologiczne i inne założenia przyjmowane przez Hobbesa nie muszą być ściśle prawdziwe w odniesieniu do każdego ludzkiego zachowania [...] Nie jest on egoistą w sensie psychologicznym. Przyjmowane przez niego założenia co do podstawowych ludzkich interesów muszą być jedynie wystarczająco wiarygodne, żeby ukazywać podstawowe wpływy, jakim podlega ludzkie zachowanie w tych rodzajach sytuacji społecznych i politycznych, które go interesują $a^{17}$.

Z tej perspektywy, z którą wypada się zgodzić, człowiek nie jest postrzegany już tak jednostronnie, jak chce Fukuyama. Nie rządzi nim już jedynie popęd samozachowawczy stowarzyszony z próżnością czy potrzebą uznania, choć nadal odgrywają one w jego życiu znaczącą rolę ${ }^{18}$. Przejawiają się one

\footnotetext{
${ }^{17}$ J. Rawls, Wykłady z historii filozofii polityki, tłum. S. Szymański, Warszawa 2010, s. 103.

${ }^{18}$ Por. następującą uwagę Hobbesa: „Każdy człowiek bowiem uważa na to, by jego towarzysz go cenił w tym samym stopniu, w jakim on sam siebie ceni. A na wszelkie oznaki pogardy czy niedostatecznej oceny odpowiada $\mathrm{z}$ natury rzeczy tym, że usiłuje, o ile tylko ma odwagę, wymusić na tych, którzy nim pogardzają, większe uważanie, czynią im jakąś krzywdę". (T. Hobbes, Lewiatan, czyli materia, forma i władza państwa kościelnego i świeckiego, tłum. Cz. Znamierowski, Warszawa 2009, s. 206).
} 
w nim w mniejszym stopniu, a często są wręcz przytłumione przez uczucia odmiennej natury. Choć więc Hobbes pyta czytelnika, czemu zbroi się w nóż, wyruszając w podróż, w drzwiach i skrzyniach swych zaś ma wstawione zamki, dostrzega jednak w człowieku coś więcej niż tylko egoistyczną zwierzęcą naturę. Trzem głównym przyczynom waśni między ludźmi: rywalizacji, nieufności i żądzy sławy, przeciwstawia naszą zdolność kochania innych, życzliwość im okazywaną, szlachetność czynów, ich sprawiedliwość i kierowanie się w życiu cnotą. Taki jest pełny obraz człowieka; nie jest więc on ani zły, ani dobry. Jego lepiej wyważoną naturę najlepiej zaś chyba oddaje uwaga Hobbesa dotycząca powodów, dla których człowiek pragnie pokoju: „Uczucia, które skłaniają ludzi do pokoju, to strach przed śmiercią, pragnienie takich rzeczy, jakie są niezbędne do wygodnego życia, oraz nadzieja, że swą pilnością i pracą człowiek będzie mógł je zdobyć. Rozum zaś poddaje wygodne warunki pokoju, na których ludzie mogą dojść do zgody. Te warunki pokoju to normy, które inaczej nazywają się prawami natury"19. Nie są więc to jakieś złe skłonności, a i człowiek nimi się kierujący raczej nie przypomina wilka.

$\mathrm{Z}$ pewnością również nie można negatywnie określić natury człowieka, którego obraz naszkicował Jan Jakub Rousseau. Ten zwolennik stanu natury i wielki piewca żyjącego w nim szczęśliwego, choć nieco leniwego, dwunożnego zwierzęcia, odmalował go w nieco jaśniejszych barwach niż jego zacny poprzednik Hobbes. Wprawdzie obaj opisywali stan natury, to jednak francuski filozof nie poszedł jego śladem. W Rozprawie o pochodzeniu i podstawach nierówności między ludźmi w ten oto sposób odnosił się do jego koncepcji:

Nie wnioskujmy jednak wraz z Hobbesem, że z chwilą, gdy o dobroci nie ma żadnego pojęcia, człowiek jest tym samym z natury zły; że jest występny, ponieważ nie zna cnoty; że bliźnim swoim zawsze odmawia przysług, których

${ }^{19}$ T. Hobbes, dz. cyt., s. 210. Podobne uczucie życzliwości wobec takiej postawy życiowej wywołuje następujący fragment dotyczący tym razem jednak stanu wojny: „Tak więc wszystko, co się odnosi do czasu wojny, w którym każdy człowiek jest nieprzyjacielem każdego innego, to odnosi się również do czasu, w którym ludzie żyją bez żadnego innego zabezpieczenia niż to, jakie im daje własna siła i własna inwencja. W takim stanie nie ma miejsca na pracowitość, albowiem niepewny jest owoc pracy; i co za tym idzie, nie ma miejsca na uprawę ziemi ani na żeglowanie, nie ma bowiem żadnego pożytku z dóbr, które mogą być przywiezione morzem; nie ma wygodnego budownictwa; nie ma narzędzi do poruszania i przesuwania rzeczy, co wymaga wiele siły; nie ma wiedzy o powierzchni ziemi ani obliczania czasu, ani sztuki, ani umiejętności, ani sztuki słowa, ani społeczności. A co najgorsze, jest bezustanny strach i niebezpieczeństwo gwałtownej śmierci. I życie człowieka jest samotne, biedne, bez słońca, zwierzęce i krótkie." (T. Hobbes, dz. cyt., s. 207). 
w swoim przekonaniu nie jest im winien; ani że w oparciu o prawo, które sobie słusznie przyznaje do potrzebnych mu przedmiotów, popada w szaleństwo, by się uważać za jedynego właściciela świata całego. Hobbes doskonale wiedział, czym grzeszą wszystkie wysunięte przez nowoczesnych definicje prawa naturalnego; ale wnioski, jakie wyciąga ze swojej własnej, wskazują, że bierze ją w sensie niemniej fałszywym. Biorąc za punkt wyjścia zasady, które na początku ustalił, autor ten powinien był twierdzić, że ponieważ w stanie natury dbałość człowieka o własne życie najmniej zagraża życiu drugiego, stan ten najbardziej ze wszystkich sprzyja utrzymaniu pokoju i jest dla rodzaju ludzkiego najodpowiedniejszy. On tymczasem twierdzi coś wręcz przeciwnego, bo do troski człowieka dzikiego o samo tylko życie włączył najniefortunniej potrzebę zaspokojenia całego mnóstwa namiętności, które są dziełem społeczeństwa i ze względu na które koniecznością stały się prawa ${ }^{20}$.

Drogi interpretacji stanu natury obu autorów rozchodzą się więc u samego ich początku. Zdaniem Rousseau poglądom Hobbesa na ludzką naturę brakuje kilku niezwykle ważnych elementów. Jednym z nich jest właśnie czynnik odpowiadający za przekraczanie miłości własnej, przejawiającej się głównie w pragnieniu zachowania własnego życia. Czynnikiem tym jest litość. I choć wspominaliśmy o tym, że w koncepcji hobbesowskiej, człowiek nie jest tak egoistyczny, jak zwykło się go przedstawiać, to faktem jest, że od równie ważnej życzliwości wobec innych, jeszcze daleka droga do uczucia litości. Cnota ta, mimo tego, że dzielona czasem $\mathrm{z}$ innymi zwierzętami, wyróżnia nas pośród nich i pozwala wyraźnie określić oddzielające nas od nich granice. Jej przejawy polegają głównie na uczuciu odrazy do widoku cierpienia innych. Zdaniem Rousseau fakt, że nieraz obserwujemy ją u innych zwierząt świadczy o tym, że jest ona cnotą naturalną, tezę tę dodatkowo wzmacnia fakt, iż poprzedza ona ludzką refleksję. To z niej Rousseau wyprowadza pozostałe cnoty społeczne: wspaniałomyślność, przebaczanie, czy uczucie ludzkości, życzliwość, przyjaźń i współczucie. Człowiek żyjący w społeczeństwie nie jest tak silnie zanurzony swych uczuciach jak człowiek dziki, nie roztapia się w nich i nie daje się im porwać. Rozum bowiem powstrzymuje go przed tym, zmusza do zastanowienia się nad swym działaniem i położeniem. Jak pisze Rousseau:

${ }^{20}$ J. J. Rousseau, Rozprawa o pochodzeniu i podstawach nierówności między ludźmi, [w:] Trzy rozprawy z filozofii społecznej, tłum. H. Elzenberg, Warszawa 1956, s. 171. 
Litość jest uczuciem naturalnym; w każdej jednostce łagodzi ona samolubstwo i przez to przyczynia się do wzajemnego podtrzymywania gatunku. Ona to rzuca nas bez namysłu na pomoc tym, którzy cierpią; ona to w stanie natury starczy za prawo, za obyczaje i cnotę, z tą w dodatku różnicą na lepsze, że nikt nie doznaje pokusy oparcia się jej łagodnemu głosowi; ona to krzepkiego dzikusa powstrzyma od zabrania słabemu dziecku lub niedołężnemu starcowi zdobytego przez nich z trudnością pożywienia, o ile tylko sama spodziewa się je sobie znaleźć gdzie indziej; ona to zamiast wzniosłej zasady wyrozumianej sprawiedliwości: Czyń drugiemu to, co chcesz, by tobie czyniono, podsuwa wszystkim ludziom zasadę dobroci naturalnej, mniej doskonałą, ale może od tamtej pożyteczniejszą: Czyń dobrze samemu sobie z możliwie najmniejszą krzywdą bliźniego. Słowem, w tym to naturalnym uczuciu raczej niż w wymyślnych rozumowaniach należy szukać źródła wstrętu, którego wyrządzając krzywdę drugiemu, każdy człowiek by musiał doznawać niezależnie nawet od zasad wpojonych mu przez wychowanie ${ }^{21}$.

Stan natury, w którym kontakty między(dziko)ludzkie miały być ograniczone, cechował się naturalnością ludzkich zachowań, ich instynktownością, poddaniem się przez ludzi biegowi wydarzeń. Oznacza to, że takie cechy współczesnego Rousseau człowieka, jak próżność, pogarda, potrzeba uznania, czy szacunku, nie miały w tym stanie w ogóle miejsca. Pojawiły się dopiero wraz z powstaniem pierwszych osad. Do tego wątku wrócimy za chwilę.

Oprócz rozumu, poczucia litości i umiejętności mówienia, inną cechą odróżniającą człowieka od zwierząt jest wolna wola. Tak jak zwierzę zanurzone jest poprzez instynkt i zmysły w swym otoczeniu, tak człowiek kieruje się jeszcze swą wolną wolą. Oznacza to, że w przeciwieństwie do nich człowiek może wyłamać się z mechanicznych praw rządzących światem zwierząt i działać według własnego wyboru. Cecha ta jednak, tak często zresztą opisywana jako ukoronowanie ludzkich zdolności, nie zawsze przychodzi nam z pomocą. Odwołajmy się ponownie do koncepcji Hobbesa: człowiek targany namiętnościami jest bardzo często, jego zdaniem, zdeterminowany w swych reakcjach przez oddziaływanie nań ciał z zewnątrz. Hobbesowska wizja człowieka jest materialistyczna i mechaniczna, choć miejscami autor próbuje w niej łączyć determinizm z wolnością. Jego człowiek nie jest więc jakoś specjalnie winny tego, kim jest i jak postępuje. W koncepcji Rousseau jest natomiast odwrotnie - człowiek „staje” się poprzez życie w społeczeństwie,

${ }^{21}$ Tamże, s. 176. 
zostaje człowiekiem uspołecznionym, zyskuje przez to swoje wszelkie wady i zalety. O tych ostatnich Rousseau pisał jednak niewiele.

Wolność woli obarcza człowieka odpowiedzialnością. Z jednej strony może ona służyć za warunek moralności, z drugiej jednak może umożliwić mu wybór złej drogi życiowej. Zdaniem Rousseau ta ostatnia możliwość może być zrealizowana dopiero $\mathrm{w}$ społeczności. Pierwotne wrastanie w kulturę, postępujące wraz z rozwojem społeczności, związane jest z jeszcze jedną cechą typowo ludzką - zdolnością do doskonalenia się. W grupie zwierząt określone, niespotykane w innych stadach zachowania mogą być nawet powielane przez kilka osobników, na przykład zręczne rozłupywanie przez małpy orzecha kokosowego o ostry kamień, lecz jednak z chwilą wymarcia stada, to osiągnięcie zanika. Rousseau twierdzi, że podobnie rzecz musiała wyglądać w przypadku człowieka dzikiego. Tak więc z początku doskonalenie się ograniczone było do poszczególnych jednostek. Dlaczego nie powtórzyć sztuki ze strącaniem kamieniem siedzącego wysoko na drzewie zwierzęcia? A dlaczego nie wprawiać się przy tym jeszcze bardziej i nie eksperymentować z różnymi kamieniami i gałęziami? Może z czasem dziki wyspecjalizowałby się w rzucie dzidą lub w strzelaniu z procy. Jednak bez innych ludzi, którym mógłby te umiejętności przekazać, całą swą wiedzę zabierał do krainy wiecznych łowów. Życie wśród ludzi sprawia, że wszystko wygląda inaczej. Pozostając w samotności, nie mając możliwości tak współpracy, jak waśni z innymi, zyskiwał jednak coś w zamian. Z perspektywy panujących później moralności można to określić mianem czystości moralnej i nieskażeniem wiedzą z drzewa poznania dobra i zła.

Nikt nie byłby tak nieszczęsny - pisze Rousseau - jak człowiek dziki oślepiony wiedzą, targany namiętnościami, rozmyślający nad stanem innym niż jego własny. Opatrznościowe to było i mądre urządzenie, że te zdolności, które potencjalnie w nim tkwiły, rozwinęły się dopiero wraz z możnościami ich zastosowania, by nie stać się dlań ani przed czasem zbyteczne i uciążliwe, ani $\mathrm{w}$ chwili rzeczywistej potrzeby spóźnione i bezużyteczne. Instynkt był dla niego tym wszystkim, czego mu w stanie natury było potrzeba do życia; ukształcony rozum to tylko to, czego mu potrzeba w życiu społecznym. Widać od razu, że ludzie w tym stanie, nie utrzymując żadnych ze sobą stosunków natury moralnej ani też żadnych względem siebie obowiązków nie znając, nie mogli być ani źli, ani dobrzy i nie mieli ani cnót, ani przywar22 .

${ }^{22}$ Tamże, s. 170. 
Nie było niczego zewnętrznego, co mogło ich jakoś określić lub poklasyfikować, poza - rzecz jasna - fizycznymi uwarunkowaniami jednostki i jej naturalnego otoczenia. Związek człowieka i przyrody, rozgrywający się w tak rozmaitych warunkach, skutkuje $\mathrm{z}$ czasem wyodrębnieniem się różnych ludów żyjących, a to nad wodą, a to w cieniu gór, raz w mroźnym klimacie, innym razem w ciepłym. To przystosowanie dotyczy zarówno jednostek, jak i całych grup. Jednak życie stadne, bo chyba tak najtrafniej należałoby określać pierwsze próby jednoczenia się ludzi, diametralnie zmieniło dotychczasowe życie dzikiego.

Przyjrzyjmy się więc tym społecznościom i temu, co życie w nich przyniosło człowiekowi. Zobaczymy przy tym to, co najbardziej interesowało Fukuyamę, a więc miłość własną (amour-propre), która dopiero teraz mogła w pełni się ujawnić. Rawls charakteryzuje ją w ten sposób:

Kiedy jednak odróżniliśmy się od innych zwierząt za sprawą rozwoju kulturowego - za sprawą języka i prostych form organizacji społecznej (rodzin i małych grup) - zaczęliśmy troszczyć się o dwie rzeczy: po pierwsze, o nasz naturalny dobrobyt i środki potrzebne do życia, i po drugie, o to, co inni o nas myślą, oraz o względne położenie w naszej grupie społecznej. To pierwsze jest przedmiotem amour de soi (przyrodzonej miłości samego siebie), która jest troską o własne dobro, co pokazują określone naturalne potrzeby wspólne człowiekowi i innym zwierzętom. To drugie jest przedmiotem amour-propre (miłości własnej), odrębnej formy zainteresowania sobą, która powstaje tylko $\mathrm{w}$ społeczeństwie. Jest to naturalne zainteresowanie bezpiecznym położeniem $\mathrm{w}$ stosunku do innych i obejmuje potrzebę bycia akceptowanym na równi z innymi ${ }^{23}$.

Naturalna amour-propre jest więc potrzebą, którą z życzliwością powinniśmy powitać w wachlarzu uczuć ludzkiej natury. Nie prowadzi nas ona bowiem do złych uczynków, a w tym do próżności i wywyższania się nad innych ludzi. Te zjawiają się dopiero z jej wypaczeniem. Nienaturalna amour-propre przejawia się wówczas $\mathrm{w}$ pysze $\mathrm{i}$ arogancji, $\mathrm{w}$ potrzebie uznania innych za gorszych, chęci panowania nad nimi i podporządkowania ich sobie. Dobrze znamy tę ludzką cechę, Rousseau też ją dostrzegał, przyglądając się współczesnym mu ludziom i ich relacjom. Widział jak ludzie zdobywali niesłusznie przywileje, w niezasłużony sposób okrywali się chwałą, byli rządni władzy i nieustannie knuli przeciwko sobie. Życie, jakie znał,

\footnotetext{
${ }^{23}$ J. Rawls, dz. cyt., s. 276.
} 
uważał za szczyt degeneracji, która rozpoczęła się dużo wcześniej. Jej źródeł upatrywał bowiem w pierwszych zalążkach społeczności.

Jak już wspomniałem, paleta barw użytych przez Rousseau do odmalowania człowieka dzikiego i jego pierwszych kroków na drodze do uspołecznienia, jest o wiele jaśniejsza i cieplejsza niż ta, której używał Hobbes. Jednocześnie obrazy francuskiego filozofa są pełne szczegółów, te zaś pozwalają nam lepiej ożywić je we własnej wyobraźni i jako konkretne wyobrażenia, zrozumieć je i przewidywać ich konsekwencje. Spróbujmy więc odmalować ten świat, w którym wspomniana wynaturzona amour-propre dopiero wybija się na pierwszy plan naszego życia i coraz częściej mąci spokój jego dawnego biegu. Zdaniem Rousseau wszystko zaczęło się z chwilą, gdy człowiek dostrzegł wartość w pomocy innych. Wzajemne potrzeby zmusiły wreszcie ludzi do jednoczenia się i zakładania pierwszych osad. Dużo łatwiej wówczas można było wspólnie osaczyć zwierzynę w lesie, czy we dwójkę zbudować większy i lepszy od poprzedniego szałas. Z chwilą jednak, gdy w gromadzie przybywało osób, zaczęto dostrzegać potrzebę specjalizacji prac, jakie mogły grupie przynieść korzyści. Początkowy podział na polujących mężczyzn i pilnujące domowego ogniska kobiety przestawał się sprawdzać. Nie wszyscy mężczyźni musieli polować. Ci o większej tężyźnie fizycznej nadal mogli oddawać się tym czynnościom, lecz ich słabsi bracia zostawali w domach i bądź to uprawiali ziemie, bądź wytwarzali przydatne narzędzia. Z czasem wyspecjalizowały się poszczególne „zawody”, prosta zaś wymiana zabitego zwierza za zboże przestała być atrakcyjna dla obu stron. Zauważono przy tym, że niektóre prace nie wymagały tak dużego zaangażowania oraz nakładów sił i czasu jak inne. Zaczęły więc zarysowywać się pierwsze podziały związane z posiadaniem i dystrybucją dóbr materialnych. Jak wiemy, po nierównościach naturalnych, był to pierwszy krok do wzrostu nierówności między ludźmi. Nas jednak interesuje bardziej to, jak w tym okresie dochodziło do wypaczenia amour-propre.

Zmieniał się status społeczny ludzi, wynikało to oczywiście z obserwacji innych i dostrzeżenia faktu, że pewne cechy cieszą się większym poważaniem niż inne. Zaczęto zatem dostrzegać w silnych mężach przywódców, w sprawnych i zręcznych rzemieślników, a piękne kobiety przykuwały swą urodą uwagę wszystkich. Okazało się wówczas, że przymioty poszczególnych osób mogły kogoś wyróżnić i sprawić, że będzie podziwiany, lub też przeciwnie, przekreślić jego szanse na lepsza partię czy podziw. 
Każdy zaczął się przyglądać innym i pragnąć - zauważa Rousseau - by i jemu się przyglądano, i uznanie publiczne nabrało ceny. Kto najlepiej śpiewał lub tańczył, kto górował siłą, urodą, zręcznością albo wymową, tego poważano najwięcej; i to stało się pierwszym krokiem ku nierówności, a jednocześnie ku występkom: z tych pierwszych wyróżnień narodziły się z jednej strony próżność i wzgarda, z drugiej - wstyd i uczucie zawiści; z fermentacji zaś spowodowanej przez te nowe zaczyny powstały w końcu skomplikowane wytwory na zgubę niewinności i szczęścia ${ }^{24}$.

Ludzie nauczyli się przyglądać innym, porównywać ich, wartościować i oceniać, dostrzegać znaczenie mimiki twarzy, gestu, grymasu czy nerwowości zachowań. Niektórzy tę sztukę posunęli jeszcze dalej i zdołali posiąść zdolność rozpoznawania prawdy skrywanej za spojrzeniem; byli bardziej przenikliwi od innych, dużo widzieli i rozumieli, choć nie nadawali się ani do polowania, ani uprawy ziemi czy wytapiania metali. Mieli więc więcej czasu, by podpatrywać ludzi i przyrodę. Swą wiedzę mogli wykorzystać na różny sposób, od leczenia ziołami ran bliźnich zdobytych na polowaniach, po przewidywanie opadów i wróżenie z kości. Wyspecjalizowali się w nowej dziedzinie i mogli zaspokajać swą potrzebę uznania, otrzymując jednocześnie legitymizację do pozostania w osadzie dzięki swej „przydatności”. Jednak wśród zamieszkujących w takiej wspólnocie byli i tacy, którzy nie potrafili niczym się wykazać, szybko jednak spostrzegli, że wystarczy stwarzać pozory, że innym będzie się tylko wydawało, iż posiadają oni cenne przymioty. Rousseau tak opisuje ten moment w historii ludzkości:

Wszystkie oto nasze zdolności rozwinęły się, pamięć i wyobraźnia działają, miłość własna jest pobudzona, rozum wprawiony w ruch, umysł doszedł do takiego prawie stopnia doskonałości, do jakiego jest w ogóle zdolny. Wszystkie naturalne cechy są czynne, miejsce w hierarchii i los każdego ustalone w zależności nie tylko od mienia i od możności przynoszenia pożytku lub szkody, lecz także od bystrości umysłu, piękności, siły, zręczności, położonych zasług, talentów; że zaś były to jedyne przymioty, dzięki którym się zyskiwało szacunek, wyszło wkrótce na to, że trzeba było albo je posiadać, albo sobie nadawać pozory ich posiadania; chcąc się w życiu urządzić korzystnie, trzeba było okazać się innym, niż się było w rzeczywistości. Być a wydawać się - te dwie rzeczy stały się czymś zgoła różnym; $\mathrm{z}$ tej to różnicy wynikły przepych, którym się imponuje, podstęp, którym wyprowadza się w pole, i wszystkie od tych dwóch nieodłączne, kroczące w ich orszaku występki. Z drugiej strony, człowiek, z wolnego

\footnotetext{
${ }^{24}$ J. J. Rousseau, dz. cyt., s. 194.
} 
i niezależnego, jakim był dotąd, jest teraz oto - za sprawą mnóstwa nowych potrzeb - podległy całej, że tak powiem, naturze, zwłaszcza zaś reszcie ludzi, których się w pewnym sensie staje niewolnikiem tam nawet, gdzie się staje ich panem: $\mathrm{w}$ bogactwie potrzebuje ich usług, w biedzie - pomocy; nie pozwala mu obyć się bez nich również i pozycja pośrednia. Musi zatem ciągle się strać o zainteresowanie ich swoim losem i o to, by w pracy na jego korzyść znajdowali korzyść własną, jeżeli nie prawdziwą, to urojoną: to zaś czyni go wobec jednych chytrym i szczwanym, wobec drugich władczym i twardym, zmuszając go do okłamywania wszystkich, których potrzebuje, o ile nie może napędzić im strachu ani w przysłużeniu się im nie widzi jakiegoś interesu własnego ${ }^{25}$.

Potrzeba uznania stowarzysza się więc z podstępnością, chytrością i - jak by to powiedział Kant $-\mathrm{z}$ przedmiotowym traktowaniem innych jedynie jako środków do realizacji własnych celów. Naturalna moralność, z jej ukoronowaniem w postaci przedrefleksyjnej litości, zaczyna więc trząść się posadach. Miłość własna, w jej wypaczonej formie, zaczyna coraz częściej dochodzić do głosu w działaniach pozwalających ustawić nam się w życiu. Wolne jednostki - jak postrzegał je Rousseau - stają się wówczas podstępne i przebiegłe, stają się takimi, jakimi on sam na co dzień widział swych współczesnych. Wypaczona miłość własna jest więc - zgodnie z tym, co pisał Fukuyama - rzeczywiście silną ludzką pobudką do działań. Z pewnością też jest formą potrzeby uznania i zyskania w oczach innych. Tego rodzaju sprężyna w mechanizmie ludzkich zachowań na pewno często popycha nas w określonym kierunku. Skoro jednak jest tak silna, to po raz kolejny powinniśmy postawić pytanie o to, czy możliwe jest jej powstrzymanie. Czy thymos można opanować, czy można zatamować jej stale napływające fale, budując zapory w postaci instytucji demokracji liberalnej? Wszak poradziła sobie z wrodzoną nam litością, a my, czymże my chcemy ją poskromić? Odpowiadając na te pytania, musimy pamiętać, że dla Rousseau źródłem wypaczonej amour-propre jest społeczeństwo, kultura, a więc na pewno i funkcjonujące w niej instytucje. Czy zatem coś, co ją wywołało będzie mogło również ją powstrzymać?

${ }^{25}$ Tamże, s. 201. 


\section{Abstract \\ The Last Man and the Idea of Generation; or Fukuyama Discovering Human Nature}

Keywords: Fukuyama, last man, history, human nature, struggle for appreciation, thymos, history development, Hobbes, Rousseau, Gasset

The aim of the article is to verify a thesis Fukuyama once advanced: the forthcoming end of history is related to the replacing of human need for appreciation by equality and mutual appreciation last men achieve in liberal democracies. I also analyze the conception of human nature which Fukuyama takes for granted and treats as the base for defining the essence of the last man. Another question I consider concerns the role of Platon's thymos and can be stated as follows: is it justified to draw such far reaching conclusions from the notion as Fukuyama does in The Las Man? To answer the question I confront Fukuyama's reflections concerning thymos with Hobbes' and Rousseau's understanding of the notion, and the idea of the end of history with the idea of generation proposed by Josè Ortega y Gasset. 